\title{
Características Morfológicas de Ovarios y Ovocitos de Nutrias (Myocastor coypus) en Condiciones de Criadero
}

\author{
Morphological Characteristics of Ovaries and Oocytes of \\ Otters (Myocastor coypus), in Breeding Conditions
}

Clara Larocca; Danilo Fila; Yael Filipiak \& William Pérez

LAROCCA, C.; FILA, D.; FILIPIAK, Y. \& PÉREZ, W. Características morfológicas de ovarios y ovocitos de nutrias (Myocastor coypus) en condiciones de criadero. Int. J. Morphol., 29(2):424-426, 2011.

RESUMEN: El objetivo del presente trabajo fue estudiar las características morfológicas de los ovarios y ovocitos de la nutria (Myocastor coypus, coypu) en las diferentes estaciones del año y etapas del ciclo estral. La nutria (MC) es un roedor autóctono de Sudamérica, muy utilizado en la industria peletera. Se sacrificaron 20 hembras, de un peso promedio de 4996,2 g recogiéndose muestras vaginales para realizar colpocitología y determinar el momento del ciclo estral, 11 se faenaron en invierno de las cuales 7 estaban en anestro, 1 en proestro y 3 en diestro y 9 en verano, encontrándose 1 en anestro, 1 en proestro y 7 en diestro. Cada ovario fue transportado en una solución de cloruro de sodio isotónico estéril a $37^{\circ} \mathrm{C}$ al laboratorio. Los ovarios fueron pesados y medidos y se desmenuzaron en placas de Petri con 2 agujas n²8, bajo microscopio estereoscópico. Se identificaron los ovocitos, se lavaron en solución Buffer Fosfato Salino (PBS) y se caracterizaron en A, B y C. Los resultados de las medias y desviación típica de los pesos de los ovarios fueron: 0,304 g (0,062); largo 9,05 mm $(0,19)$ y ancho 5,05 mm $(0,69)$. Se realizó el análisis de varianza para la condición de los ovocitos, y no se constató diferencias estadísticamente significativas asociadas a la estación ni a la condición estral sobre la condición de los ovocitos ( $\mathrm{p}<0,05)$. En lo que respecta al número de cuerpos lúteos, se realizó el test de Fisher, y se observaron diferencias significativas entre las etapas del ciclo estral (diestro versus anestro) con una $\mathrm{F}=20,57(\mathrm{p}=0,0001)$, entre las estaciones del año (verano versus invierno) con una $\mathrm{F}=72,21(\mathrm{p}=0,0000)$ y la interacción entre las etapas y las estaciones con una $\mathrm{F}=10,29(\mathrm{p}=0,0018)$.

PALABRAS CLAVE: Nutrias; Ovocitos; Ovarios.

\section{INTRODUCCIÓN}

La nutria (Myocastor coypus) es un roedor de amplia utilización en la industria peletera de escala mundial. Este animal pertenece al orden Rodentia, suborden Caviomorpha, familia Capromydae (Nedbal et al., 1994). Es una especie autóctona de Sudamérica, con una distribución continental que cubre la Pampa y litoral Argentino, Paraguay, Uruguay y el sur de Brasil (Iudica \& Alberio, 1995). La naturaleza de aspectos relacionados con reproducción en roedores es variada. Desde los primeros trabajos a principios de los años 20 del siglo pasado, tanto en los cuises (cerdos de Guinea) (Stockard \& Papanicolau, 1917), ratas (Long \& Evans, 1920, 1921, 1922) y ratones (Allen, 1922), se ha demostrado que el ciclo estral en roedores está determinado por cambios estándar en los tipos celulares que se observan en frotis vaginales (Felipe et al., 2001a). La nutria permanece en estado reproductivo a través del año (poliéstrica continua), con un ciclo de 23-40 días de duración, según lo determinado en varios estudios tanto en cautiverio como en libertad (Ehrlich, 1966; Newson, 1966) y manifiesta su maduración sexual rondando los 6 meses de edad, cuando su peso corporal está entre los 3 y 4 kilogramos (Iudica \& Alberio). La caracterización de los tipos celulares y cuantificación de los cambios de las diferentes etapas del ciclo estral de la nutria fue ampliamente descripto por Felipe et al. (2001b).

\section{MATERIAL Y MÉTODO}

Se sacrificaron y pesaron 20 nutrias en condiciones de criadero, 11 hembras en invierno y 9 en verano, registrándose la edad de cada animal. Se recogieron muestras con hisopos en las vaginas para hacer colpocitología 
con el fin de determinar el momento del ciclo estral, según la metodología de Felipe et al. (2001a). Cada ovario fue colocado en un tubo cónico con solución de cloruro de aodio isotónico estéril y fueron transportados a una temperatura de $37^{\circ} \mathrm{C}$ en una caja de material aislante. En el laboratorio, se extrajeron los ovarios, se midió el largo y el ancho de cada uno y se pesaron. Posteriormente cada ovario se colocó en una placa de Petri de $90 \mathrm{~mm}$ de diámetro, contándose los cuerpos lúteos (CL). Se agregó sobre cada ovario $500 \mu \mathrm{l}$ de medio buffer fosfato salino (PBS) y se desmenuzaron con dos agujas $\mathrm{n}^{\circ} 28$. Posteriormente se lavaron 2 veces en medio PBS y bajo microscopio estereoscópico se ubicaron los ovocitos categorizándolos en A, B y C, usando el criterio de Liebfried \& First (1979) para ovocitos bovinos. Se realizó como análisis estadístico el cálculo de las medias y desviaciones típicas de las variables: peso total, longitud y ancho de los ovarios. Se efectuó un análisis factorial de varianza, utilizando como factores la estación del año, el estado estral y la interacción entre ambos. Las variables de respuesta estudiadas fueron: número de ovocitos según las diferentes calidades $(\mathrm{A}, \mathrm{B}, \mathrm{C})$ y número de cuerpos lúteos por nutria. En los ensayos de hipótesis se utilizó el nivel de significación 0,05 .

\section{RESULTADOS Y DISCUSIÓN}

Las nutrias presentaron una edad promedio de 13,1 meses con desviación típica de 3,9 meses y su peso corporal medio fue de 4996,2 g con desviación típica 346,7 g. De las faenadas en invierno, 7 estaban en anestro, 1 en proestro y 3 en diestro. En lo que respecta a las faenadas en verano, 1 estaba en anestro, 1 en proestro y 7 en diestro. Los ovarios, de aspecto lobulado, presentaban folículos haciendo prominencia de la superficie en distintos estados de evolución y cuerpos lúteos. Los resultados de las medias y desviación típica de los pesos de los ovarios fueron: $0,304 \mathrm{~g}(0,062)$; largo $9,05 \mathrm{~mm}(0,19)$ y ancho 5,05 $\mathrm{mm}(0,69)$. Los resultados de las calidades de los ovocitos en relación a las diferentes etapas del ciclo estral y la estación del año, se visualiza en la Tabla I. Se realizó el análisis de varianza para la condición de los ovocitos, y no se constató diferencias estadísticamente significativas asociadas a la estación ni a la condición estral sobre la condición de los ovocitos $(\mathrm{p}<0,05)$. En lo que respecta al número de cuerpos lúteos, se realizó el test de Fisher, y se observaron diferencias significativas entre las etapas del ciclo estral (diestro versus anestro) con una $\mathrm{F}=20,57$ ( $\mathrm{p}=0,0001$ ), entre las estaciones del año (verano versus invierno) con una $\mathrm{F}=72,21(\mathrm{p}=0,0000)$ y la interacción entre las etapas y las estaciones con una $\mathrm{F}=10,29(\mathrm{p}=0,0018)$.
Tabla I. Diferentes calidades de ovocitos y cuerpos lúteos según estación o etapa del ciclo.

\begin{tabular}{lccccc}
\hline & \multicolumn{3}{c}{ Ovocitos } & Presencia CL \\
\cline { 2 - 5 } & $\mathbf{n}$ & $\mathbf{A}$ & $\mathbf{B}$ & $\mathbf{C}$ & \\
\hline Diestro & 10 & 51 & 34 & 50 & $67 \mathrm{a}$ \\
Anestro & 8 & 62 & 20 & 69 & $5 \mathrm{~b}$ \\
Verano & 9 & 78 & 31 & 71 & $71 \mathrm{c}$ \\
Invierno & 11 & 74 & 27 & 60 & $11 \mathrm{~d}$ \\
\hline
\end{tabular}

Diferentes letras significan diferencias estadísticas para $\mathrm{p}<0,005$.

Las estructuras ováricas presentes en los ovarios de hembras sexualmente maduras muestran semejanzas con la morfología de los ovarios de otras especies como concluyen Felipe \& Masson (2005). Los CL observados serían aquellos de desarrollo completo e intermedio ya que los de desarrollo inicial difícilmente hacen saliencia en la superficie del ovario según describen Felipe et al., (1999). La mayor presencia de cuerpos lúteos en el diestro en relación al anestro es coincidente con lo ocurre en otras especies. Teniendo en cuenta que es una especie poliéstrica continúa, las diferencias estadísticas encontradas podrían estar relacionadas con la crudeza del invierno (factor nutricional) que tuvieron que soportar y no con una situación de estacionalidad reproductiva.

\section{AGRADECIMIENTOS}

Reconocimiento al Ing. Agr. Sebastián Moure por brindar las nutrias y las instalaciones. Se agradece la colaboración en el análisis estadístico del Dr. Luis Lavarello.

LAROCCA, C.; FILA, D.; FILIPIAK, Y. \& PÉREZ, W. Morphological characteristics of ovaries and oocytes of otters (Myocastor coypus), in breeding conditions. Int. J. Morphol., 29(2):424-426, 2011.

SUMMARY: The aim of this work was to study the morphological characteristics of ovaries and oocytes of the otter (Myocastor coypus, coypu) in different seasons and stages of the estrous cycle. The otter (MC) is a rodent native to South America and is widely used in the fur industry. Twenty females with a mean weight of $4996.2 \mathrm{~g}$ were sacrificed, vaginal swabs or colpocytology were collected and the time of the estrous cycle was determined. Eleven were slaughtered in winter, of which 7 were in anestrus, 1 in proestrus, and 3 in diestrus; of the 9 slaughtered in summer, 1 was in anestrus, 1 in proestrus and 7 in diestrus. Each ovary was transported to the laboratory in a solution of sterile isotonic sodium chloride at $37^{\circ} \mathrm{C}$. The ovaries were weighed and measured and crumbled into Petry dishes with 
two No.28 needles, under a stereoscopic microscope. Oocytes were identified, washed in phosphate buffered saline solution (PBS) and were characterized as A, B and C. The results of mean and standard deviation of the weights of the ovaries were:

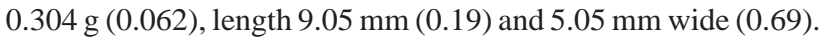
We performed the analysis of variance for the condition of oocytes and found no statistically significant differences associated with the station or estrus status on the status of the oocytes ( $\mathrm{p}<0.05)$. Regarding the number of corpora lutea, Fisher's test was used, with significant differences between stages of estrous cycle (diestrus vs. anestrus) with $\mathrm{F}=20.57(\mathrm{p}=0.0001)$ between seasons (summer vs. winter) with $\mathrm{F}=72.21(\mathrm{p}=0.0000)$ and interaction between the stages and stations with an $F=10.29(p=0.0018)$.

KEY WORDS: Otters; Oocytes; Ovaries.

\section{REFERENCIAS BIBLIOGRÁFICAS}

Allen, E. The oestrus cycle in the mouse. Am. J. Anat., 30:297-371, 1922.

Ehrlich, S. Ecological aspects of reproduction in nutria, Myocastor coypus Mol. Mammalia, 30:142-52, 1966.

Felipe, A.; Cabodevilla, J. \& Callejas, S. Anatomicohistological characteristics of the ovary of the coypu (Myocastor coypus). Anat. Histol. Embryol., 28:89-95, 1999.

Felipe, A.; Cabodevilla, J. \& Callejas, S. Characterization of the estrous cycle of the Myocastor coypus (coypu) by means of exfoliative colpocytology. J. Neotrop. Mastazool., 8(2):129-37, 2001a.

Felipe, A.; Teruel, M.; Callejas, S. \& Cabodevilla, J. Description of the characteristics of oocytes and zygotes of coypu (Myocastor coypus). Rev. Chil. Anat., 19(2):161-5, $2001 b$.

Felipe, A. \& Masson, P. Un modelo descriptivo del sistema reproductor hembra coipo (Myocastor coypus). I: el ovario. Redvet, 6(12):1-22. 2005. Disponible en: <http:// www.veterinaria.org/revistas/redvet/n121205.html>.

Iudica, C. E. \& Alberio, R. H. Preliminary study of the sexual cycle of the South-american nutria (Myocastor coypus) by the method of exfoliative colpocitology. Scientifur, 19(1):33-42, 1995.

Liebfried, L. \& First, N. L. Characterization of bovine follicular oocytes and their ability to mature in vitro. $J$. Anim. Sci., 48:76-86, 1979.
Long, J. A. \& Evans, H. M. The oestrus cycle in the rat and other studies in the physiology of reproduction. Anat. Rec., 21(1):41-9, 1920.

Long, J. A. \& Evans, H. M. Further studies in the physiology of reproduction. Anat. Rec-, 21(1):41-9, 1921.

Long, J. A. \& Evans, H. M. The oestrus cycle in the rat and its associated phenomena. Mem. Univ. Calif., 6:1-148, 1922.

Nedbal, M. A.; Allard, M. N. \& Honeycutt, R. L. Molecular systematic of histricognath rodents: evidence from the mitochondrial 12 Sr RNA gene. Mol. Phylogenet. Evol., 3:206-20, 1994.

Newson, R. M. Reproduction in the feral coypu (Myocastor coypus). Symp. Zool. Soc. Lond., 15:323-34, 1966.

Stockard, C. R. \& Papanicolau, G. N. The existence of a typical oestrus cycle in the guinea pig with a study of its histological an physiological changes. Am. J. Anat., 22:225-84, 1917.

Dirección para correspondencia:

Dra. Clara Larocca

Facultad de Veterinaria.

Las Places $1550 \mathrm{C}$.

P. 11600.

Montevideo

URUGUAY.

Email: claralarocca@hotmail.com

Recibido : 20-01-2011

Aceptado: 23-03-2011 